\title{
Needles of Abies Sibirica in the Treatment of Subclinical Mastitis in Cows
}

\author{
M.S. Danilov ${ }^{1}$, N.V. Valitova ${ }^{1 *}$, A.L. Vorobyov ${ }^{1}$, E.A. \\ Asangaliev1, A.A. Kalachev ${ }^{2}$
}

${ }^{1}$ Department of Water and Forest Resources, East Kazakhstan State Technical University named after D. Serikbayev, 19 Serikbaev St., Ust-Kamenogorsk 070010, Kazakhstan. ${ }^{2}$ Altai branch of the Kazakh Scientific Research Institute of Forest and Agroforestry, 13a Ostrovsky St., Ridder, Kazakhstan 071302, *Corresponding author e-mail: valitova.ekst@bk.ru

Journal of Livestock Science (ISSN online 2277-6214) 10:9-18

Received on 19/9/2018; Accepted on 1/2/2019

doi. 10.33259/JLivestSci.2019.9-18

\begin{abstract}
Study of the therapeutic effectiveness of "Abies-masti", a medication based on Siberian fir needles, in the treatment of subclinical mastitis in cows. The therapeutic effectiveness of the medication was studied in cows with subclinical mastitis. "Abies-masti" was rubbed into the skin of the inflamed lobes twice a day after milking until the clinical recovery of the cows. Hematological blood tests, as well as the examination of milk samples from the affected parts of the udder before the treatment and in 5 and 12 days from the beginning of the treatment were carried out according to the methods generally accepted in veterinary practice. The authors of the research established that when using the medication "Abiesmasti" to treat cows with subclinical mustitis, the clinical recovery of animals under production conditions was achieved within $3.14 \pm 0.26$ days. The therapeutic effectiveness of "Abies-masti" was 91.4-92.6\%. The authors proved that the normalization of the hematological parameters, as well as the organoleptic, physico-chemical, and microbiological indicators of milk occurs on the 5th day from the beginning of the treatment. The cost of the treatment amounted to $\$ 0.45$ per animal. The restoration of the functional state of the mammary gland and the recovery of cows with the use of the given phytomedication is achieved within a shorter period than with the help of other anti-mastitis medications. 48 hours after the last application of the medication, the milk of the recovered animals fully meets the requirements of GOST. The result is achieved thanks to the composition of the medication and the properties of its components, which have a bactericidal effect against the causative agent, increase the protective forces of the macroorganism and ensure the stability of the therapeutic effect. The authors of the research prove the effectiveness and expediency of using this medication based on Siberian fir needles for the treatment of subclinical mastitis in cows.
\end{abstract}

Keywords: mastitis; cow; therapy; Abies sibirica; phytomedication. 


\section{Introduction}

Mastitis in cows (MC) is a disease of great economic importance in the dairy industry all over the world since from 15-30 to 50-75\% of animals on dairy farms may get the disease during one year (Sultanov et al., 2015; Abebe et al., 2016). The damage inflicted by MC to dairy farming includes a dicrease in milk yield (10-70\%), a deterioration in milk quality (8\%), a shortage of offsprings $(8 \%)$, as well as an increase in the costs for feeding and keeping animals (Sultanov et al., 2015). Up to 30\% of diseased animals are subject to forced and premature culling due to irreversible changes in the breast tissues (Sultanov et al., 2015; Gamayunov et al., 2016). At the farm level, the frequency of the development of clinical mastitis (CM) in cows is 3.4-11.5\% (Abebe et al., 2016; Bhat et al., 2017). The incidence rate of subclinical mastitis (SCM) is much higher, in particular, from 30 to $82.6 \%$ higher than the number of cows with MC (Nyman et al., 2007). At the same time, bacterial mastitis is recorded in 78.6-86.9\% of cases (Danilov, 2015; Suleiman et al., 2017). In the milk of cows with SCM, bacteria are detected in $79.5 \%$ of cases (Danilov, 2015). MC is the most widespread among non-communicable diseases in the Republic of Kazakhstan (from 32.4\% to 42.7\%) (Danilov, 2015). The incidence rate of MC varies considerably in the republic. During the lactation period, CM and SCM are recorded in 5,35$17.4 \%$ and 23,5-82.6\% of cases (Danilov, 2015; Zhumanov, 2016).

Most often, the causative agents of MC include St.Aureus (51.2-60.87\%), staphylococci (13.04\%), Str. uberis (4.35\%), Str. dysgalactiae (8.69\%), and E. coli (13.04\%) (Abebe et al., 2016; Bhat et al., 2017). The causative agents of SCM are as follows: St.aureus (36.8\%), Ps. aeruginosa (17.8\%), St. epidermidis (16.1\%), Klebsiella spp. (9.5\%), Micrococcus spp. (6.3\%), and E. coli (4.9\%) (Suleiman et al., 2017; Zhumanov, 2016). In some cases, associations of microorganisms are isolated. The greatest number of associations, 32.1\%, is observed with purulent-catarrhal mastitis. (Danilov, 2015).

At present, the treatment of MC is based on antimicrobial therapy. In the Republic of Kazakhstan (RK), the treatment and prevention of MC is carried out in accordance with a manual. According to the latter, the treatment should be comprehensive and aimed at suppressing the vital activity of the microflora, increasing the resistance factors, eliminating the soreness and swelling of the udder, as well as restoring the physiological function of the affected quarters (GOST 31449-2013). As all over the world, etiotropic therapy is based on the use of antimicrobial (alone or in various combinations), as well as enzyme medications of bacteria, probiotics, phytoncides, etc. (GOST 31449-2013).

The consumption of antibiotics in food animals is growing all over the world and sometimes exceeds the amount consumed by people (Van Bunnik \& Woolhouse, 2017). This is due to the fact that in addition to being used for medicinal purposes, antibitics serve as growth stimulants for animals (Van den Bogaard \& Stobberingh, 1999). However, excessive use of antibiotics leads to drug resistance in MC agents (Van Boeckel et al., 2017). Studies have reliably proven the resistibility of staphylococci and other pathogens isolated from the milk of the inflamed breasts of cows to tetracycline, penicillin, oxacillin, cefoxitin (Srednik et al., 2017), aminoglycoside, macrolide, lincosamide (Rato et al., 2013), ampicillin, and sulfadimethoxin (Saini et al., 2012). The authors identified E. coli strains that are insensitive to penicillin (Zhumanov, 2016). In some countries, more than $70 \%$ of the isolated strains demonstrate resistance to various antibiotics. Multiple drug resistance to several categories of antibiotics is most common (Wang et al., 2015). Thus, widespread and unsystematic use of antibiotics led to the formation of drug-resistant strains of MC agents, which, in turn, is a risk factor for the emergence of antibiotic resistance in human pathogens (Van den Bogaard \& Stobberingh, 1999). The degree of dependence of these factors on each other has not yet been identified. However, studies in this area are already underway (Van Bunnik \& Woolhouse, 2017).

At present, it is known that antibiotics accumulated in milk cause allergies and food poisoning in people (Zhumanov, 2016; Larionov et al., 2016). In this context, the development of alternative medications based on natural components has become a priority in animal therapy. The development and introduction of new anti-mastitis medications into veterinary practice is also a relevant issue. These products should be environmentally friendly and safe; have a high therapeutic effect; and not cause microorganisms' resistance to them. Medications based on natural components, for example, animal tissues, minerals, and plants, fully meet the above requirements.

Today, about $25 \%$ of veterinary medications around the world are obtained from plants (Rastogi et al., 2015; Suroowan et al., 2017). Whole plants or parts thereof are used to prepare different medications (Balakrishnan et al., 2017; Rastogi et al., 2015). Studies confirm that plants and plant-based medications have an inhibitory and antimicrobial effect on MC agents (Pașca et al., 2017). Therefore, the use of medicinal plants implies a promising perspective for the treatment of MC. When determining the chemical composition and structure of active substances of medicinal plants and their medications by 
using modern high-precision methods (Makarova et al., 2013; Yong-Li et al., 2015), it was established that the essential oils of plants include various chemicals, for example, thymol, foams, and cineoles. A large number of terpenoids and terpenes provide oils with geroprotective properties and promote the regeneration of tissues (Kudryavtseva et al., 2016; Wenming et al., 2016). In $80 \%$ of cases, the minimum inhibitory concentration (MIC) of plant essential oils ranges from 15.02 to $31.08 \mu \mathrm{g} / \mathrm{ml}$ (Ksouri et al., 2017). In this regard, herbal components in the composition of various medications are used to treat animal diseases, including MC (Bartha et al., 2015; Ksouri et al., 2017). Plant extracts that are obtained by using solvents of different polarity, for example, acetone, ethanol, petroleum ether and water, dilute hydrochloric acid ( $\mathrm{pH} 4.0$ ) at $70^{\circ} \mathrm{C}$ (Wang et al., 2015), and $\mathrm{NH}_{3}$ solution ( $\mathrm{pH} \sim 8.5$ ), also contain a large number of active substances. $\mathrm{NH}_{4} \mathrm{OH}$ demonstrates the greatest extracting ability (Danilov, 2015; Shakhmatov et al., 2015).

Given the urgency of the problem, scientists around the world study the issue of using medicinal plants for the treatment of MC. In various states of India, about $75 \%$ of naturally grown medicinal plants are used to treat a number of animal diseases, including MC (Rastogi et al., 2015). Of the 441 formulations based on the use of various plants, 353 are safe and effective (Balakrishnan et al., 2017). In the Russian Federation, a number of new anti-mastitis medications have been developed: fuzvet-A (from pumpkin seeds), vivatone (based on a decoction of herbs and ammonia), "Penosept" (based on a common nettle extract), "Mastig" (a plant complex), etc. (Belkin et al., 2006). The effectiveness of plant-based pihtoin ointment and trauma-gel used as independent agents in the treatment of SCM was 16.7 and $63.2 \%$ respectively, while their combined application allowed achieving $100 \%$ recovery in cows (Larionov et al., 2014). In the Republic of Kazakhstan, for the treatment of MC during the lactation period, when the use of antibiotics affects the product, it is recommended to use the medication of Vitamin B based on essential oils of pine, juniper, cedar, and echinacea purpurea. Intercysternal application of $20 \%$ infusions of herbs (common nettle, bearberry, perforate St John's-wort, yarrow medicinal, etc.) is also highly recommended. The therapeutic effectiveness of a five-time application is $91.5-96.0 \%$ (GOST 314492013).

In recent years, in the territory of the CIS countries, medications based on the components of A. Sibirica are being used in medical and veterinary practice. Siberian fir (A. sibirica) is a coniferous tree of the pine family widespread in coniferous forests of East Kazakhstan. It gives fir, decorations, infusions, tinctures, and extracts (Dilbarkhanov et al., 2005). The needles are the most valuable part of the fir. Extracts from fir needles contain tannins, essential oils, $\beta$-carotene, ascorbic acid, flavonoids, and glycosides. The content of the latter is quite high (Danilov, 2015). Fir oil has a high etheric value - 177.7 \pm 8.4 (Danilov, 2011). In the composition of the essential oil extracted from needles A. Sibirica, bornal acetate $(34.21 \%)$, borneol $(24.16 \pm 3.12 \%)$, $\alpha$-terpenes $(6.72 \%)$ (Pavolotskii, 1959), and aliphatic compounds, for example, pinene, myrcene, cadinene, camphene, etc., (up to $41.20 \%$ ) were detected as the main constituents that largely determine its biological activity (Pavolotskii, 1959). In addition, pectins (Shakhmatov et al., 2015) and pectin polysaccharide (Makarova et al., 2013) were extracted from A. sibirica needles. Complex anti-mastitis preparations that contain the essential oil of A. Sibirica has a beneficial effect on regenerative processes, increases skin elasticity, softens the skin, heals wounds in shorter time, demonstrates antibacterial. The antimicrobial activity of the medication against mastitis pathogens is quite high (the zone of growth retardation ranges from 15 to $49.5 \mathrm{~mm}$ ) (Tarasov et al., 2013).

The authors of this research studied the chemical composition as well as the antimicrobial effect of extracts of A. sibirica needles by the method of serial dilution in the MPB against inflammation of the mammary glands of cows with mastitis, strains of St. Aureus, St. epidermidis, Str. agalactiae, and Str. Uberis. The authors revealed that in 1:64 - 1:256 dilutions, extracts demonstrate bactericidal activity against all test-bacteria. The highest antibacterial properties were observed in ammonia extracts (1:26, 1:256) (Danilov, 2010). Within the framework of the scientific research on the topic " Biotechnology of Medications Based on Siberian Fir Needles For Cows with Mastitis" for grant financing of the Ministry of Education and Science of the Republic of Kazakhstan (state registration number 0109PK0191, inventory number 505 from September 16, 2009) in 2009-2012, the researchers of the East Kazakhstan State Technical University named after. D. Serikbaev (EKSTU, Ust-Kamenogorsk) developed "Abies-masti", a medication based on A. sibirica needles, for the prevention and treatment of MC. In addition to the extract of A. sibirica needles with ammonia and fir oil, the composition of the medication includes dimethyl sulfoxide and an ointment base. Dimethyl sulfoxide, which is able to rapidly penetrate into the skin and transfer other substances, is included in the composition of the ointment to increase the transdermal transfer of active substances. Besides, it serves as a local anti-inflammatory and analgesic component. The resulting medication is a yellow-colored homogeneous emulsion with a pleasant smell of needles and $\mathrm{pH}$ of 7.8-7.9. The authors of the medication obtained an innovative patent of the Republic of Kazakhstan 
(RK) and developed an enterprise standard (Danilov, 2010, 2011). "Abies-masti" has an antimicrobial effect against Str. agalactiae and St. aureus and generates a zone of growth retardation in bacteria on MPA in diameters of $17.6 \pm 1.5$ and $18.21 .6 \mathrm{~mm}$ respectively. In addition, the medication has antiinflammatory and healing properties. It has no allergenic and sensitizing activity, and demonstrates a moderate toxic effect $\left(\mathrm{LD}_{50}=160 \mathrm{~cm}^{3} / \mathrm{kg}\right.$ ) (Danilov, 2015).

The aim of this work is to study the therapeutic effect of the "Abies-masti" medication in the treatment of SCM. The relevance of the research is related to the use of herbal medications for the treatment of SCM in cows with the aim of increasing the effectiveness of the therapy, reducing the duration and costs of treatment, minimizing the use of antibiotics, and obtaining environmentally friendly livestock products that are harmless to humans.

\section{Materials and methods}

The work was carried out in 2012-2015 in "Bagration", a peasant farm (p/f) in the East Kazakhstan Region (EKR), as well as in the base of the East Kazakstan Regional Veterinary Laboratory. The incidence rate of MC on livestock farms of Bagration $\mathrm{p} / \mathrm{f}$ is $12.6 \%-28.4 \%$ of the total number of animals. The authors conducted experimental studies on the effectiveness of the medication on cows with SCM. The established diagnosis was based on clinical signs, the positive reaction with a $2 \%$ solution of mastidine, a creaming test and counting of somatic cells in milk samples according to Khilkevich.

For the scientific-economic experiment, the authors selected 14 cows with SCM. By the principle of analogs, they formed two groups of seven cows: an experimental group and a control group. For the production experiment, the authors selected 253 cows with SCM and divided them into two groups: an experimental group (190 cows) and a control group (63 cows). In the experimental groups, the authors of the research used the medication "Abies-masti", which was applied to the inflamed parts of the udder twice a day after milking. In the control group, the medication "Percutane" was used. The latter was applied externally: it was sprayed from a distance of $10-15 \mathrm{~cm}$ from the affected surface. Both medications were used prior to the clinical recovery of cows and the two-time negative reaction with mastidine.

The diagnosis of MC and the control of animals' recovery was performed through clinical and laboratory blood tests and milk samples from the affected lobes. Hematologic examinations of blood and the study of milk samples were conducted in the base of the East Kazakhstan Regional Veterinary Laboratory. To determine the number of red blood cells, white blood cells, hemoglobin, leukocyte formula, and the total protein and its fractions in blood content, the authors of the research used the diagnostic kits "Biola-test Lachema", as well as the generally accepted methods in veterinary practice (Kondrakhin et al., 2004). The organoleptic, physicochemical, and microbiological indicators of milk (protein and fat mass fraction, acidity, density, mass fraction of non-fat dry milk (NFDM), content of somatic cells, number of mesophilic aerobic and facultative anaerobic microorganisms) were checked for compliance with GOST 31449-2013 by generally accepted methods (GOST 31449-2013; Kondrakhin et al., 2004). All the indicators were measured prior to the treatment and in 5 and 12 days after the start of the treatment.

The authors of the research processed the experimental data by the method of variational statistics using the computer program Microsoft Office Excel 2007. The reliability degree of the difference in the obtained data was determined by the Student's test.

\section{Results}

As a result of the scientific-economic experiment, recovery of all the animals was recorded. During the treatment of SCM in cows using the "Abies-masti" medication, soreness and tightness in inflamed udder quarters decreased in 1-2 days. In the course of the further application of the phytomedication, all the animals recovered within 2-4 days. The medication allowed achieving restoration of the functional state of the mammary gland.

In the control group, the authors of the experiment observed an improvement in the overall condition of the animals in 1-2 days. Recovery was achieved on the 4-7-th days of treatment. In order to assess the condition of animals, the control over the course of the recovery process, and the occurrence of relapses of mastitis, the authors of the research applied laboratory tests of blood and milk. The results of the experiment are presented in Tables 1 and 2. 
Table 1. Hematologic Blood Indicators in the Treatment of Cows with SCM ( $=7$; * $-\mathrm{P}<0.05)$

\begin{tabular}{|c|c|c|c|c|c|c|c|c|c|}
\hline \multirow{2}{*}{\multicolumn{3}{|c|}{ Indicators }} & \multirow[b]{2}{*}{ Norm } & \multicolumn{3}{|c|}{ "Abies-masti" } & \multicolumn{3}{|c|}{ Percutane } \\
\hline & & & & $\begin{array}{c}\text { before } \\
\text { treatment }\end{array}$ & in 5 days & in 12 days & $\begin{array}{c}\text { before } \\
\text { treatment }\end{array}$ & in 5 days & in 12 days \\
\hline \multicolumn{3}{|c|}{ Red blood cells $\left(10^{12} / \mathrm{L}\right)$} & $5-7.5$ & $5.51 \pm 0.31$ & $5.76 \pm 0.23$ & $5.98 \pm 0.28$ & $5.49 \pm 0.22$ & $5.68 \pm 0.26$ & 24 \\
\hline \multicolumn{3}{|c|}{ Hemoglobin $(\mathrm{g} / \mathrm{L})$} & $90-120$ & $96.2 \pm 0.8$ & $99.3 \pm 0.7$ & $102.9 \pm 0.9$ & $96.3 \pm 0.7$ & $98.4 \pm 0.6$ & 103 \\
\hline \multicolumn{3}{|c|}{ White blood cells $\left(10^{9} / \mathrm{L}\right)$} & $6-12$ & $10.16 \pm 0.12$ & $8.75 \pm 0.12 *$ & $7.31 \pm 0.12$ & $10.39 \pm 0.13$ & $9.11 \pm 0.11$ & 7.39 \\
\hline \multirow{7}{*}{ 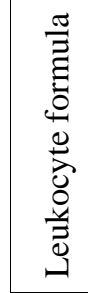 } & \multicolumn{2}{|c|}{ Basophils (\%) } & $0-2$ & $1.7 \pm 0.03$ & $1.2 \pm 0.04$ & $1.1 \pm 0.03$ & $1.8 \pm 0.04$ & $1.6 \pm 0.02$ & $1.2 \pm$ \\
\hline & \multicolumn{2}{|c|}{ Eosinophils (\%) } & $3-10$ & $8.77 \pm 0.3$ & $7.68 \pm 0.3$ & $7.28 \pm 0.3$ & $8.71 \pm 0.3$ & $7.82 \pm 0.3$ & $7.6 \pm 0.3$ \\
\hline & \multirow{3}{*}{ 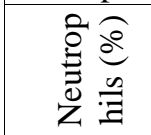 } & Young & - & $0.7 \pm 0.02$ & $0 *$ & 0 & $0.6 \pm 0.02$ & $0.2 \pm 0.02$ & 0 \\
\hline & & Stab & $3-10$ & $7.16 \pm 0.05$ & $6.3 \pm 0.03 *$ & & & & \\
\hline & & Segmented & $18-30$ & $22.3 \pm 0.06$ & $23.4 \pm 0.08^{*}$ & $24.2 \pm 0.1$ & $22.4 \pm 0.09$ & $22.6 \pm 0.06$ & $23.7 \pm 0.05$ \\
\hline & \multicolumn{2}{|c|}{ Lymphocytes (\%) } & $47-66$ & $53.47 \pm 0.1$ & $55.12 \pm 0.12$ & $56.42 \pm 0.1$ & $53.3 \pm 0.13$ & $54.78 \pm 0.12$ & $56.0 \pm 0.14$ \\
\hline & \multicolumn{2}{|c|}{ Monocytes (\%) } & $2-7$ & $5.9 \pm 0.08$ & $6.3 \pm 0.07$ & $6.4 \pm 0.07$ & $6.0 \pm 0.07$ & $6.2 \pm 0.06$ & $6.4 \pm 0.08$ \\
\hline \multicolumn{3}{|c|}{ Total protein $(\mathrm{g} / \mathrm{L})$} & $68-90$ & $77.5 \pm 0.53$ & $82.4 \pm 0.42$ & $84.7 \pm 0.64$ & $78.1 \pm 0.52$ & $79.8 \pm 0.51$ & $80.47 \pm 0.43$ \\
\hline \multicolumn{3}{|c|}{ Albumins (\%) } & $39-48$ & $43.2 \pm 0.4$ & $45.7 \pm 0.1 *$ & $47.6 \pm 0.5$ & $43.7 \pm 0.2$ & $44.1 \pm 0.3$ & $47.3 \pm 0.5$ \\
\hline \multicolumn{3}{|c|}{$\alpha$-globulins (\%) } & $12-21$ & $18.8 \pm 0.7$ & $16.1 \pm 0.4^{*}$ & $13.4 \pm 0.3$ & $18.5 \pm 0.7$ & $16.9 \pm 0.25$ & $14.3 \pm 0.36$ \\
\hline \multicolumn{3}{|c|}{$\beta$ - globulins (\%) } & $12-16$ & $14.6 \pm 0.7$ & $13.0 \pm 0.4^{*}$ & $11.7 \pm 0.3$ & $14.3 \pm 0.3$ & $13.7 \pm 0.26$ & $12.1 \pm 0.31$ \\
\hline \multicolumn{3}{|c|}{$\gamma$ - globulins (\%) } & $20-30$ & $23.4 \pm 0.46$ & $26.1 \pm 0.5^{*}$ & $27.3 \pm 0.39$ & $23.5 \pm 0.37$ & $25.3 \pm 0.42$ & $26.3 \pm 0.32$ \\
\hline
\end{tabular}

Table 2. Physico-Chemical and Microbiological Indicators of Milk During the Treatment of Cows with SCM ( $\mathrm{n}=7$; *- $\mathrm{P}<0.05)$

\begin{tabular}{|c|c|c|c|c|c|c|c|}
\hline \multirow[b]{2}{*}{ Indicators } & \multirow[b]{2}{*}{ Norm } & \multicolumn{3}{|c|}{ "Abies-masti" } & \multicolumn{3}{|c|}{ Percutane } \\
\hline & & $\begin{array}{c}\text { before } \\
\text { treatment }\end{array}$ & in 5 days & in 12 days & $\begin{array}{c}\text { before } \\
\text { treatment }\end{array}$ & in 5 days & in 12 days \\
\hline Fat mass fraction, $\%$, not $<$ & 2.8 & $2.95 \pm 0.05$ & $3.11 \pm 0.03^{*}$ & $3.21 \pm 0.04 *$ & $2.92 \pm 0.04$ & $3.01 \pm 0.03$ & $3.12 \pm 0.01$ \\
\hline Protein mass fraction, $\%$, not $<$ & 2.8 & $3.03 \pm 0.06$ & $3.13 \pm 0.03 *$ & $3.21 \pm 0.02 *$ & $3.02 \pm 0.03$ & $3.05 \pm 0.02$ & $3.15 \pm 0.02$ \\
\hline Acidity, ${ }^{\circ} \mathrm{T}$ & $6.0-21.0$ & $13.9 \pm 0.08$ & $16.5 \pm 0.08 *$ & $16.8 \pm 0.06^{*}$ & $13.8 \pm 0.07$ & $16.1 \pm 0.05$ & $16.6 \pm 0.07$ \\
\hline SMP, $\%$, not $<$ & 8.2 & $8.24 \pm 0.04$ & $8.48 \pm 0.05^{*}$ & $8.51 \pm 0.04 *$ & $8.21 \pm 0.04$ & $8.32 \pm 0.04$ & $8.4 \pm 0.03$ \\
\hline Density, $\mathrm{kg} / \mathrm{m}^{3}$, not $<$ & 1027.0 & $1026.1 \pm 0.2$ & $1027.4 \pm 0.13$ & $1027.7 \pm 0.18^{*}$ & $1026.2 \pm 0.13$ & $1027.4 \pm 0.11$ & $1027.5 \pm 0.24$ \\
\hline $\begin{array}{l}\text { The content of somatic cells in } 1 \\
\mathrm{~cm}^{3}, \text { not }>\end{array}$ & $4.0 \cdot 10^{5}$ & $7.2 \cdot 10^{5} \pm 0.13$ & $3.6 \cdot 10^{5} \pm 0.12^{*}$ & $3.1 \cdot 10^{5} \pm 0.15^{*}$ & $7.3 \cdot 10^{5} \pm 0.3$ & $4.0 \cdot 10^{5} \pm 0.13$ & $3.6 \cdot 10^{5} \pm 0.17$ \\
\hline QMAFAnM, CFU $/ \mathrm{cm}^{3}$, not > & $1.0 \cdot 10^{5}$ & $1.7 \cdot 10^{5} \pm 0.07$ & $0.8 \cdot 10^{5} \pm 0.06^{*}$ & $0.7 \cdot 10^{5} \pm 0.05^{*}$ & $1.8 \cdot 10^{5} \pm 0.08$ & $1.0 \cdot 10^{5} \pm 0.04$ & $0.9 \cdot 10^{5} \pm 0.07$ \\
\hline
\end{tabular}


Table 1 shows that in cows with SCM, most hematological indicators are within the physiological norm. However, it is possible to observe some mild changes in the blood, in particular, emergence of neutrophils, a slight increase in the number of neutrophils and a dicrease in the number of segmented neutrophils, as well as an increase in the number of basophils. White blood cells are also within the norm, but their number is close to the upper limit value. The norm of the $\gamma$-globulin content is $20-40 \%$. In both groups, this indicator is $23.4 \%$ and $23.5 \%$, which indicates a low immune response of the body. The treatment of cows led to a change in the indicators under study. On the fifth day of treatment, in the experimental group the authors of the experiment observed total disappearance of young neutrophils, a significant decrease in the control of the number of stab neutrophils, and an increase in the number of segmented neutrophils. There was a significant change, in particular, a decrease in the number of white blood cells by $11.7 \%(\mathrm{P}<0.05)$ in the experimental group and by $1.4 \%$ in the control group, which was due to the decrease in the impact of the pathogen and the decrease in the inflammatory reaction in the mammary gland as a result of treatment.

In both groups, the authors noted normalization of protein-carbohydrate metabolism, and the amount of total protein increased by $6.3 \%$ and $2.2 \%$. In experimental animals, there was a redistribution of protein fractions upwords in relation to the control of the amount of $\gamma$-globulinin by 5\%, which indicates the activation of the protective forces of the body.

During the treatment, the authors of the experiment observed normalization of the secretion of the mammary gland in the cows (Table 2). As can be seen from Table 2, before the treatment, in the cows of the experimental and control groups, the protein mass fraction (3.03 and 3.02\%), content of fat mass fraction (2.95 and 2.92\%), and NFDM (8.24 and 8.21\%) were within the norms. In both groups, the authors noted a decrease in the milk density by 0.08 and $0.08 \%$, and acidity by 13.1 and $13.75 \%$; the number of somatic cells exceeded the norm by 1.8 and 1.82 times, and the number of mesophilic aerobic and facultative anaerobic microorganisms exceeded the norm by 1.7 and 1.8 times respectively. These changes indicate an inflammatory process in the mammary gland.

On the fifth day from the treatment with the medication "Abies-masti", the authors observed normalization of milk composition by all the parameters studied. The mass fraction of fat and protein increased by $5.4 \%$ and $3.3 \%$ respectively, NFDM - by $3.9 \%$, density - by $0.13 \%$, and acidity - by $18.7 \%$. In addition, there the number of somatic cells, and mesophilic aerobic and facultative anaerobic microorganisms decreased by 2 and 2.1 times respectively. The changes in the above parameters indicate an improvement in the quality of milk and the absence of inflammation in the mammary gland.

During the treatment of SCM in cows with Percutane, there was an increase in the fat mass fraction by $3.1 \%$, protein - by $1 \%$, NFDM - by $1.3 \%$, acidity - by $16.7 \%$, and density - by $0.12 \%$. The number of somatic cells, and mesophilic aerobic and facultative anaerobic microorganisms decreased by 1.8 times each. The comparative analysis of the changes in the milk composition in the experimental and control groups showed that on the fifth day, in the milk of the experimental animals the content of fat, protein, and NFDM, as well as milk acidity was significantly higher, in particular, by $3.3 \%, 2.62 \%, 2.5 \%$, and $1.9 \%$ respectively, and the number of somatic cells, and mesophilic aerobic and facultative anaerobic microorganisms was significantly lower, in particular, by $10 \%$ and $20 \%$ respectively, than in the control animals. On the 12th day of treatment, the organoleptic characteristics, as well as the physicochemical and microbiological parameters of milk in both groups corresponded to the norms, which confirms the absence of disease relapse. Thus, the results of the examinations of blood and milk samples indicate gradual normalization of the identified parameters. At the same time, the recovery intensity in the control group manifested itself more slowly than in the animals in the experimental group. In all the cases, the recovery was confirmed by a negative reaction with a $2 \%$ solution of mastidine, a creaming test, and counting of somatic cells in the secretion of the cured lobes.

The results of the production experiment are presented in Table 3. As a result of the application of "Abies-masti" in production conditions, $92.6 \%$ of sick cows recovered, and $91.4 \%$ of udder quarters were cured in the experimental group. In the control group, these indicators were $69.8 \%$ and $72.7 \%$ respectively.

The recovery duration of sick animals in the experimental group was significantly shorter than in the control group (by 1.46 days). In cows that did not recover within the specified period, the authors of the experiment identified the antibiotic susceptibility of the microflora isolated from the secretion of inflamed mammary glands. In addition to the main medication, the authors of the experiment further used "Pharmazin-200" according to its instructions for use. In the process of further treatment, the remaining animals were also treated. The cost of veterinary measures and the treatment of SCM with the medications "Abies-masti" and Percutane were \$0.45 and \$2.45 per animal respectively. 
Table 3. The Effectiveness of the Treatment of SCM in cows $\left(*_{-} \mathrm{P}<0.05\right)$

\begin{tabular}{|c|c|c|c|c|c|}
\hline \multirow{2}{*}{ Animal group } & \multicolumn{2}{|c|}{ Number of } & \multicolumn{2}{|c|}{ Treated } & Treatment duration \\
\cline { 2 - 6 } & $\begin{array}{c}\text { sick } \\
\text { cows }\end{array}$ & $\begin{array}{c}\text { affected udder } \\
\text { quaters }\end{array}$ & cows & $\begin{array}{c}\text { udder } \\
\text { quarters }\end{array}$ & \begin{tabular}{c} 
(days) \\
\hline Experimental
\end{tabular} \\
\hline Control & 63 & 233 & 176 & 213 & $3.14 \pm 0.26^{*}$ \\
\hline
\end{tabular}

\section{Discussion}

The change in the physico-chemical and microbiological indicators of milk indicate an inflammatory process of the mammary gland. At the same time, there is a change in the quantitative ratio between the constituent parts, in particular, a decrease in the content of dry matter, milk fat, titrated acidity, and density, and an increase in NFDM (QMAFAnM ) and the number of somatic cells (Belozertseva et al., 2013; Larionov et al., 2014).

In the course of treatment with the medication "Abies-masti", as well as during the treatment with other herbal medications, there is a normalization of indicators and restoration of the functional state of the mammary gland (Larionov et al., 2014). The increase in the number of agranulocytes and segmented neutrophils in the blood affirms the activation of protective mechanisms and an increase in the overall resistance of the body. The reduction of eosinophils and the absence of young neutrophils in the recovered animals indicate a reduction of the antigenic effect on the hematopoietic organs. The changes in protein fractions in blood, in particular, an increase in $\gamma$-globulin and a decrease in $\alpha$ - and $\beta$-globulin, indicate the recovery of animals and normalization of the immune response. So, during the treatment of SCM, the authors observed a pronounced therapeutic effect and immunomodulating properties of the phytomedication (Sultanov et al., 2015; Bhatt et al., 2014).

According to the data of a number of authors, the effectiveness of herbal medications ranged from 16 to $96 \%$ (Belkin et al., 2006; Sultanov et al., 2015). In this research, the therapeutic effect of the "Abies-masti" medication was 91.4-92.2\%, and the recovery rate is faster than in animals treated with a medication containing furacilin and ethacridine lactate.

An important positive factor is related to the stability of the therapeutic effect of the medications made on the basis of coniferous species. Even with a 20-time passaging of pathogenic Staphylococcus strains on nutrient media containing sub-bactericidal doses of the A. Sibirica needle extract, there is an oppression of their plasma-coagulating, hemolytic, and dermonecrotic properties. At the same time, there is no increase in the resistance to the antibacterial activity of the medication (Komarova, 1967).

The authors of this article came to the conclusion that in the treatment of lactating cows with SCM, the higher therapeutic effect of the "Abies-masti" medication is related to the complex effect of its components, which have antimicrobial, anti-inflammatory, regenerative, reparative, adaptogenic, and immunostimulating effects. The use of herbal medications for the treatment of SCM is economically justified since the average costs for this treatment are 5.4 or more times lower than when using treatment with traditional chemotherapeutic agents (Danilov, 2015; Tarasov et al., 2013). In addition, herbal medications do not become the cause of milk culling due to its contamination with antibiotics.

It is necessary to point out that there are sufficient quantities of raw materials for the production of this medication since A. sibirica is the main forest-forming species in the mountain forest of the Kazakh Altai. After each annual logging, a huge amoung of logging residues, including needles, are accumulated and can be used for the production of the medication. The use of the "Abies-masti" medication in the treatment of cows with SCM demonstrated a high therapeutic effect (91.4-92.6\%) with a sufficiently fast recovery period for the sick animals $(3.14 \pm 0.26$ days) and no relapse of the disease. Thus, the medication under study shows a pronounced therapeutic effect, and the data of this research confirm the potential of this medication as alternative treatment of cows with SCM. The authors of the research did not carry out a comparative analysis between the results obtained and other data due to the absence of similar studies.

\section{Conclusions}

During the treatment of SCM in cows using the "Abies-masti" medication, the authors of the research found out that its therapeutic effect is $91.4-92.6 \%$. They experimentally proved that the period of clinical recovery with "Abies-masti" treatment is significantly less: $3.14 \pm 0.26$ days. On the fifth day of treatment, the authors noted normalization of the hematological idicators, protein-carbohydrate metabolism, as well as organoleptic, physicochemical, and microbiological indicators of milk. Two days after the recovery and the last application of the medication, all the indicators of the milk of cows fully 
met the requirements of GOST and was suitable for consumption. The cost of the treatment of SCM in cows with the "Abies-masti" medication is \$ 0.45 per animal. Thus, the "Abies-masti" medication is an effective, environmentally friendly, simple to manufacture, cheap, and effective means for the treatment of cows with SCM. The results of the research confirm the relevance of studying the therapeutic effect of the "Abies-masti" medication in the treatment of clinical mastitis in cows.

\section{Acknowledgements}

The authors of this article express their gratitude to the staff of the East Kazakhstan Regional Veterinary Laboratory for assisting in the analysis, to the head of "Bagration" p/f of the East Kazakhstan Oblast for assistance in carrying out scientific-economic and production experiments, and to everybody who participated in the examination and adoption of manuscripts, i.e. reviewers, editors, as well as the members of the editorial board of the magazine, which is going to publish this article. The sections "Materials and Methods" and "Results" were prepared by Danilov M.S., Vorobyov A.L., Asangaliev E.A., and Kalachev A.A.. All the other sections were made by Valitova N.V.

The medication "Abies-masti" was developed within the framework of the domestic grant of the Ministry of Education and Science of the Republic of Kazakhstan on the topic "Biotechnology of Medications Based on Siberian Fir Needles For Cows with Mastitis" (State registration number 0109RK0191, inventory number 505 from 16.09.2009) in 2009-2012.

\section{References}

1) Abebe R, Hatiya H, Abera M, Megersa B, Asmare K, 2016. Bovine mastitis: prevalence, risk factors and isolation of Staphylococcus aureus in dairy herds at Hawassa milk shed, South Ethiopia. BMC Veterinary Research, 12: 270. DOI: https://doi.org/10.1186/s12917-016-0905-3

2) Balakrishnan NMN, Punniamurthy N, Kumar, SK, 2017. Ethno-veterinary Practices for Animal Health and the Associated Medicinal Plants from 24 Locations in 10 States of India Research \& Reviews. Journal of Veterinary Sciences, (3)1: 25-34.

3) Bartha SG, Quave CL, Balogh L, Papp N, 2015. Ethnoveterinary practices of Covasna County, Transylvania, Romania. Journal of Ethnobiology and Ethnomedicine, 11: 35 . DOI: https://doi.org/10.1186/s13002-015-0020-8

4) Belkin BL, Cherepakhina LA, Popkova TV, Skrebneva EN, 2006. Diagnosis and Non-Traditional Methods of Treatment of Subclinical Mastitis in Cows. Newsletter of the Orel State Agrarian University 1(1): 31-36.

5) Belozertseva NS, Fedotov SV, Derinov AV, Boltenkov VA, 2013. Peculiarities of Early Diagnosis of Subclinical Mastitis in Cows. Newsletter of the Altai State Agrarian University 5(103): 104-108.

6) Bhat AM, Soodan JS, Singh R, Dhobi IA, Hussain T, Dar MY, Mir M, 2017. Incidence of bovine clinical mastitis in Jammu region and antibiogram of isolated pathogens. Veterinary World, 10(8): 984-989. DOI: https://doi.org/10.14202/vetworld.2017.984-989

7) Bhatt VD, Shah TM, Nauriyal DS, Kunjadia AP, Joshi CG, 2014. Evaluation of a topical herbal drug for its in-vivo immunomodulatory effect on cytokines production and antibacterial activity in bovine subclinical mastitis. An International Quarterly Journal of Research in Ayurveda, 35(2): 198-205. DOI: https://doi.org/10.4103/0974-8520.146254

8) Danilov MS, 2010. Medication for the Treatment of Mastitis in Cows, "Abies-Masti", on the Basis of Siberian Fir Components, Technical Conditions: ST Republican State Enterprise 38906594-0022010.

9) Danilov MS, 2011. Medication Based on the Components of Siberian Fir Needles for the Treatment of Mastitis in Cows. Innovative Patent of the Republic of Kazakhstan No. 23945. Newsletter No. 5.

10) Danilov MS, 2015. Pharmacological Properties and Therapeutic and Prophylactic Efficacy of Phytomedications and Mineral Compounds in Mastitis in Cows. The extended abstract of Dr. habil. in Veterinary Sciences. Novosibirsk: Institute of Experimental Veterinary Science of Siberia and the Far East.

11) Dilbarkhanov RD, Ustenova GO, Berdibekov MA, Kozhanova KK, Amantaeva ME, 2005. Medications Based on Fir Oil. Message 2. Pharmacy of Kazakhstan 2: 26-27.

12) Gamayunov VM, Koltsov DN, Novikov VM, 2016. Efficiency of Primalact for Lactating Cows with Mastitis. International Scientific and Research Journal 7(49), Part 3: 28-30. DOI: 
https://doi.org/10.18454/IRJ.2016.49.061

13) GOST 31449-2013. Raw Cow Milk. Technical Conditions. Interstate Standard. ISS 67.100.10. Date of introduction* 2014-07-01 https://rosexpertpravo.ru/law/Data2/1/4293780/4293780016.pdf

14) Komarova MA, 1967. The Influence of Medications from fir needles on some biological properties of Staphylococci. In Ayzenman BYe, Bondarenko AS, Drobot'ko VG et al. (Eds.) Phytoncides, their biological role and importance for medicine and the national economy. Kiev: Naukova Dumka: 198-199.

15) Kondrakhin IP, Arkhipov AV, Levchenko VI, Talanov GA, Frolova LA, Novikov VE, 2004. Methods of Veterinary Clinical Laboratory Diagnostics: Handbook. Moscow: Colossus.

16) Ksouri S, Djebir S, Bentorki AA, Gouri A, Hadef Y, Benakhla A, 2017. Antifungal activity of essential oils extract from Origanum floribundum Munby, Rosmarinus officinalis L. and Thymus ciliatus Desf. against Candida albicans isolated from bovine clinical mastitis. Journal de Mycologie Médicale, 27(2): 245-249. DOI: https://doi.org/10.1016/j.mycmed.2017.03.004

17) Kudryavtseva A, Krasnov G, Lipatova A, Alekseev B, Maganova F, Shaposhnikov M, Fedorova M, Snezhkina A, Moskalev A, 2016. Effects of Abies sibirica terpenes on cancer- and agingassociated pathways in human cells. Oncotarget., 13;7(50): 83744-83754. DOI: https://doi.org/10.18632/oncotarget.13467

18) Larionov GA, Vyazova LM, Dmitrieva ON, Shchiptsova NV, 2014. The Influence of Herbal Medications on the Safety and Quality of Milk in Cows with Subclinical Mastitis. Bulletin of the Timiryazev Agricultural Academy, 4: 64-73.

19) Larionov GA, Vyazova LM, Tsarevsky IV, 2016. Prevention and treatment of subclinical mastitis in cows. Cheboksary: New Time.

20) Makarova EN, Patova OA, Shakhmatov EG, Kuznetsov SP, Ovodov YS, 2013. Structural studies of the pectic polysaccharide from Siberian fir (Abies sibirica Ledeb.). Carbohydrate Polymers, 15;92(2): 1817-26. DOI: https://doi.org/10.1016/j.carbpol.2012.11.038

21) Nyman AK, Ekman T, Emanuelson U, Gustafsson AH, Holtenius K, Waller KP, Sandgren CH. (2007). Risk factors associated with the incidence of veterinary-treated clinical mastitis in Swedish dairy herds with a high milk yield and a low prevalence of subclinical mastitis. Preventive Veterinary MedicinePrev, 16; 78(2):142-60.

22) Pașca C, Mărghitaș L, Dezmirean D, Bobiș O, Bonta V, Chirilă F, Matei I, Fiț N, 2017. Medicinal Plants Based Products Tested on Pathogens Isolated from Mastitis Milk. Molecules, 4;22(9). pii: E1473. DOI: https://doi.org/10.3390/molecules22091473

23) Pavolotskii ShI, 1959. Biological activity of Abies sibirica needles. Antibiotiki (Mosc). 4(1):114-5.

24) Rastogi S, Pandey MK, Prakash J, Sharma A, Singh GN, 2015. Veterinary herbal medicines in India. Pharmacognosy Reviews, 9(18): 155-163. http://doi.org/10.4103/0973-7847.162140

25) Rato MG, Bexiga R, Florindo C, Cavaco LM, Vilela CL, Santos-Sanches I, 2013. Antimicrobial resistance and molecular epidemiology of streptococci from bovine mastitis. Veterinary Microbiology, 161(3-4):286-294. DOI: https://doi.org/10.1016/j.vetmic.2012.07.043

26) Saini V, McClure JT, Scholl DT, DeVries TJ, Barkema HW, 2012. Herd-level association between antimicrobial use and antimicrobial resistance in bovine mastitis Staphylococcus aureus isolates on Canadian dairy farms. Journal of Dairy Science, 95(4): 1921-1929. DOI: https://doi.org/10.3168/jds.2011-5065

27) Shakhmatov EG, Udoratina EV, Atukmaev KV, Makarova EN, 2015. Extraction and structural characteristics of pectic polysaccharides from Abies sibirica L. Carbohydrate polymers,5(123):228-36. DOI: http://doi.org/10.1016/j.carbpol.2015.01.041

28) Srednik ME, Archambault M, Jacques M, Gentilini ER, 2017. Detection of a mecC-positive Staphylococcus saprophyticus from bovine mastitis in Argentina, In Journal of Global Antimicrobial Resistance, 10: 261-263. DOI: https://doi.org/10.1016/j.jgar.2017.05.016.

29) Suleiman TS, Karimuribo ED, Mdegela RH, 2017. Prevalence of bovine subclinical mastitis and antibiotic susceptibility patterns of major mastitis pathogens isolated in Unguja island of Zanzibar, Tanzania. Tropical Animal Health and Production, 50(2):259-266. DOI: http://doi.org/10.1007/s11250-017-1424-3

30) Sultanov AA, Ivanov NP, Gorelov YM, Namet AM, Tellyaeva MV, Sushchikh VY, Musaeva AK, Egorova NN, Espenbet TT, 2015. Recommendations for the diagnosis, prevention, and therapy of mastitis in animals. Almaty: Kazakh Scientific and Research Veterinary Institute.

31) Suroowan S, Javeed F, Ahmad M, Zafar M, Noor MJ, Kayani S, Javed A, Mahomoodally MF, 2017. Ethnoveterinary health management practices using medicinal plants in South Asia - a review. 
Veterinary Research Communications, 41(2): 147-168. DOI: https://doi.org/10.1007/s11259-0179683-Z

32) Tarasov VE, Kravtsova MK, Koba IS, Reshetka MB, Methods for the Treatment of Mastitis in Animals. RU2486905C1. 2013-07-10

33) Van Boeckel TP, Glennon EE, Chen D, Gilbert M, Robinson TP, Grenfell BT, Levin SA, Bonhoeffer S, Laxminarayan R, 2017. Reducing antimicrobial use in food animals. Science,29:357(6358): 1350-1352. DOI: https://doi.org/10.1126/science.aao1495

34) Van Bunnik BAD, Woolhouse MEJ, 2017. Modelling the impact of curtailing antibiotic usage in food animals on antibiotic resistance in humans. Royal Society Open Science, 4:161067. DOI: https://doi.org/10.1098/rsos.161067

35) Van den Bogaard, AE, Stobberingh, EE, 1999. Antibiotic usage in animals: impact on bacterial resistance and public health. Drugs, 58(4):589-607.

36) Wang D, Wang, Z, Yan Z, Wu J, Ali T, Li J, Lv Y, Han B, 2015. Bovine mastitis Staphylococcus aureus: Antibiotic susceptibility profile, resistance genes and molecular typing of methicillinresistant and methicillin-sensitive strains in China. Infection,Geneticsand Evolution, 31: 9-16. DOI: https://doi.org/10.1016/j.meegid. 2014.12.039

37) Wenming, Wu, Xu, Chen, Ye, Liu, Yanmei, Wang, Tian, Tian, Xiaoya, Zhao, Juan, Li, Hanli, Ruan. (2016). Triterpenoids from the branch and leaf of Abies fargesii. Phytochemistry,130:301312.DOI: https://doi.org/10.1016/ j.phytochem.2016.07.001

38) Yong-Li Li, Yan-Xia Gao, Hui-Zi Jin, Lei Shan Wan-Lin, Chang, Xian-Wen, Yang, Hua-Wu, Zeng, Ning, Wang, Andre, Steinmetz, Wei-Dong, Zhang, 2015. Chemical constituents of Abies fabri. Phytochemistry, 117: 135-143. DOI: https://doi.org/10.1016/j.phytochem.2015.06.012

39) Zhumanov KT, 2016. Mastitis in Cows and Control Measures: the extended abstract of Ph.D. in Veterinary Science dissertation. Almaty: Kazakh National Agrarian University. 